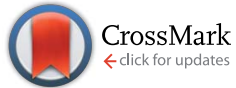

Cite this: RSC Adv., 2017, 7, 7116
Received 15th October 2016 Accepted 13th January 2017

DOI: $10.1039 / c 6 r a 25275 c$

www.rsc.org/advances

\section{Enhanced capacity and lower mean charge voltage of Li-rich cathodes for lithium ion batteries resulting from low-temperature electrochemical activation $\uparrow$}

\author{
Evan M. Erickson, ${ }^{a}$ Florian Schipper, ${ }^{a}$ Ruiyuan Tian, ${ }^{a}$ Ji-Yong Shin, $^{\mathrm{b}}$ Christoph Erk, ${ }^{\mathrm{b}}$ \\ Frederick Francois Chesneau, ${ }^{b}$ Jordan K. Lampert, ${ }^{\text {b }}$ Boris Markovsky ${ }^{a}$ \\ and Doron Aurbach*a
}

\begin{abstract}
High capacity and high energy cathodes prepared from Li-rich $0.35 \mathrm{Li}_{2} \mathrm{MnO}_{3} \cdot 0.65 \mathrm{Li}\left[\mathrm{Mn}_{0.45} \mathrm{Ni}_{0.35} \mathrm{Co}_{0.20}\right] \mathrm{O}_{2}$ materials must be activated in Li-ion cells prior to normal cycling, in order to achieve their high discharge capacity of $>250 \mathrm{~mA} \mathrm{~h} \mathrm{~g}^{-1}$. Activation is performed by charging the electrodes to potentials of 4.7-4.8 V vs. $\mathrm{Li} / \mathrm{Li}^{+}$. This communication reports on the discovery that electrochemical activation of these cathode materials at low temperatures $\left(0-15{ }^{\circ} \mathrm{C}\right)$ increases their discharge capacity, lowers average charge voltage, and diminishes voltage hysteresis. Work with the above mentioned material is reported as a representative example.
\end{abstract}

Li-rich cathode materials of the general formulae $\mathrm{Li}_{1+x^{-}}$ $\mathrm{Mn}_{0.33+y} \mathrm{Ni}_{z} \mathrm{Co}_{w} \mathrm{O}_{2}(x+y+z+w=2.66)$, are often described as two layered, structurally compatible, monoclinic $\mathrm{Li}_{2} \mathrm{MnO}_{3}(C 2)$ $m$ ) and rhombohedral $\mathrm{Li}[\mathrm{MnNiCo}] \mathrm{O}_{2}(R \overline{3} \mathrm{~m})$ components integrated on a nanoscale. ${ }^{1-3}$ This multi-phase designation remains controversial with support in the literature for a solid solution composed of a superlattice including stacking faults that have been incorrectly assigned as a separate $C 2 / m$ component. ${ }^{4-6}$ Some authors have suggested that these differences are possibly due to the wide variety of composition and synthesis techniques, with different synthesis parameters producing the solid solution or the integrated material. ${ }^{5}$ In any case, ending this controversy is beyond the scope of this short communication. For this paper, we refer to the $0.35 \mathrm{Li}_{2} \mathrm{MnO}_{3} \cdot 0.65 \mathrm{Li}\left[\mathrm{Mn}_{0.45^{-}}\right.$ $\left.\mathrm{Ni}_{0.35} \mathrm{Co}_{0.20}\right] \mathrm{O}_{2}$ material (obtained from BASF) as a two-phase system consisting of structurally integrated layered monoclinic $\mathrm{Li}_{2} \mathrm{MnO}_{3}$ and rhombohedral $\mathrm{LiMO}_{2}$ components. This conclusion is based on our recent work that provided careful Rietveld analysis of XRD patterns and electron diffraction studies of this material. ${ }^{1-3}$ This is in line with papers by Thackeray et al., which have interpreted Li-rich materials to be a composite of two phases. ${ }^{7-9}$

Li-rich cathodes offer a high discharge capacity, approaching $300 \mathrm{~mA} \mathrm{~h} \mathrm{~g}{ }^{-1}$, though this is offset somewhat by a lower

${ }^{a}$ Department of Chemistry, Faculty of Exact Sciences, Bar-Ilan University, Ramat-Gan, 5290002 Israel. E-mail: Doron.Aurbach@biu.ac.il

${ }^{b} B A S F$ SE, Ludwigshafen am Rhein, Rheinland-Pfalz, Germany

$\dagger$ Electronic supplementary information (ESI) available. See DOI: $10.1039 / \mathrm{c} 6 \mathrm{ra} 25275 \mathrm{c}$ operating average discharge voltage $(c a .3 .5 \mathrm{~V})$ than Ni-rich materials $\mathrm{Li}\left[\mathrm{Ni}_{z} \mathrm{CoMn}\right] \mathrm{O}_{2}, z>0.5 .^{10}$ Li-rich materials owe their high capacity to extraction of $\mathrm{Li}^{+}$ions from transition metal (TM) layer which are only accessible after activation at potentials $>4.5 \mathrm{~V}$ where a complex structural reorganization occurs concomitant with oxygen release from the material surface. Recent promising research by Tarascon et al. has shown that in Li-rich oxides, the $\mathrm{O}^{2-}$ anions can donate electron density during oxidation, helping to deliver the material's enormous capacity. ${ }^{\mathbf{8 1 1 - 1 4}}$ Anionic oxidation becomes more important for the advancement of Li-ion battery cathode materials as in the discovery of a new class of rocksalt materials with initial capacity ca. $300 \mathrm{~mA} \mathrm{~h} \mathrm{~g}{ }^{-1} \cdot{ }^{15}$

Returning to Li-rich materials, they suffer from a voltage and capacity fade upon cycling caused by partial migration of transition metal ions to the $\mathrm{Li}^{+}$layer, and the thermodynamic drive of the layered structure to convert partially to spinel-like phase..$^{\mathbf{1 1 6}}$ The goal of this communication is to report on our recent important finding that performing the first two cycles (the "activation" cycles) of $0.35 \mathrm{Li}_{2} \mathrm{MnO}_{3} \cdot 0.65 \mathrm{Li}\left[\mathrm{Mn}_{0.45} \mathrm{Ni}_{0.35}\right.$ $\left.\mathrm{Co}_{0.20}\right] \mathrm{O}_{2}$ cathodes at lower temperatures (e.g. 0 or $15{ }^{\circ} \mathrm{C}$ rather than $30^{\circ} \mathrm{C}$, "Low- $T$ activation") significantly increases electrode discharge capacity, decreases average charge voltage and voltage hysteresis. We demonstrate that "Low- $T$ activation" does not improve drastically discharge voltage fading or capacity fading. However, the positive effect on both capacity and average voltage is clearly evident. Hence, this paper describes an interesting effect of temperature on the activation of these materials, that further affects their performance. Since the mechanisms of activation and operation of these materials are 
very complicated, each discovery of a new phenomenon, can add further understanding about their behaviour and practical potential. This is a short communication which intends to report for the first time on the positive effect of low- $T$ activation, concentrating on the electrochemical response of these cathode materials. Full papers will follow reporting on detailed structural analysis, long-term full cell cycling data and mechanistic research. More work is required to confirm that low- $T$ activation may be used for practical stabilization of capacity and voltage of these cathode materials.

We have also tried low- $T$ activation with other formulations of Li-rich materials, showing similar results (work is in progress). We can clearly claim that what we present herein is a general phenomenon related to the family of the Li-rich cathode materials. From our knowledge, previous temperature dependence studies on similar materials did not monitor capacity differences or average voltages resulting from different activation temperatures. ${ }^{17}$ Hence, our work demonstrated herein is novel and focused on the electrochemical approach as it is sensitive enough to study the $0.35 \mathrm{Li}_{2} \mathrm{MnO}_{3} \cdot 0.65 \mathrm{Li}\left[\mathrm{Mn}_{0.45^{-}}\right.$ $\left.\mathrm{Ni}_{0.35} \mathrm{Co}_{0.20}\right] \mathrm{O}_{2}$ electrodes upon activation at 0 and $15^{\circ} \mathrm{C}$. The Lirich material was provided by BASF and its structural and morphological characteristics, as well as cycling performance were studied by us previously. ${ }^{1-3}$ Further structural information of the Li-rich material including SEM micrographs are presented in the ESI (Fig. S1, S2 and Table S1 $\dagger$ ).

Fig. 1 depicts the discharge capacity of $0.35 \mathrm{Li}_{2} \mathrm{MnO}_{3} \cdot 0.65 \mathrm{Li}$ $\left[\mathrm{Mn}_{0.45} \mathrm{Ni}_{0.35} \mathrm{Co}_{0.20}\right] \mathrm{O}_{2}$ electrodes cycled at 30 and $45{ }^{\circ} \mathrm{C}$, when cells are activated at $0-45{ }^{\circ} \mathrm{C}$. The "activation step" consisted of the first two cycles at a $\mathrm{C} / 15$ rate, to $4.7 \mathrm{~V}$ and $4.6 \mathrm{~V}$, respectively, at temperatures indicated, with further cycling details indicated in the ESI. $\uparrow$ After the activation step, the cells were subsequently cycled at the rates indicated at either 30 (Fig. 1A) or $45{ }^{\circ} \mathrm{C}$ (Fig. 1B). Interestingly in Fig. 1, lower activation temperature $(0$ and $15{ }^{\circ} \mathrm{C}$ ) of $0.35 \mathrm{Li}_{2} \mathrm{MnO}_{3} \cdot 0.65 \mathrm{Li}\left[\mathrm{Mn}_{0.45} \mathrm{Ni}_{0.35} \mathrm{Co}_{0.20}\right] \mathrm{O}_{2}$ electrodes results in remarkably higher (by 20-30 $\mathrm{mA} \mathrm{h} \mathrm{g}^{-1}$ ) discharge capacities, accompanied by smaller differences in the average charge-discharge voltages (Fig. 2). Especially affected is the charge voltage, which is stable upon cycling and lower by 50-100 mV for electrodes activated at $0{ }^{\circ} \mathrm{C}$. Discharge voltages remain within 1 std. deviation of each other (Fig. 2A). The difference between the charge and discharge voltages, the hysteresis $\Delta E$, is also lower by $50-100 \mathrm{mV}$ for electrodes activated at $0{ }^{\circ} \mathrm{C}$, for prolonged cycling (Fig. 2B).

Fig. 3 provides $\mathrm{d} Q / \mathrm{d} V$ plots and voltage profiles for the first two "activation" cycles at $0,15,30$ and $45{ }^{\circ} \mathrm{C}$, as indicated. The results of the first cycle show a clear dependence on the activation potential with temperature (peak 1). We established that as activation temperature is lower, the oxidation peak associated with activation and $\mathrm{O}_{2}$ release shifts to higher potentials, as expected (Fig. 3A and B). Indeed, when the activation temperature is $0{ }^{\circ} \mathrm{C}$, the oxidation peak $>4.5 \mathrm{~V}$ connected to $\mathrm{O}_{2}$ evolution is severely truncated, in both the first and second cycles. The diminished activation of the material's $\mathrm{Li}_{2} \mathrm{MnO}_{3}$ component results in substantially lower capacities for the cells cycled at $0{ }^{\circ} \mathrm{C}$. We note the much shorter the activation voltage plateau at $>4.5 \mathrm{~V}$ of $\mathrm{Li}_{2} \mathrm{MnO}_{3}$ at $0{ }^{\circ} \mathrm{C}$ and the charge estimated in

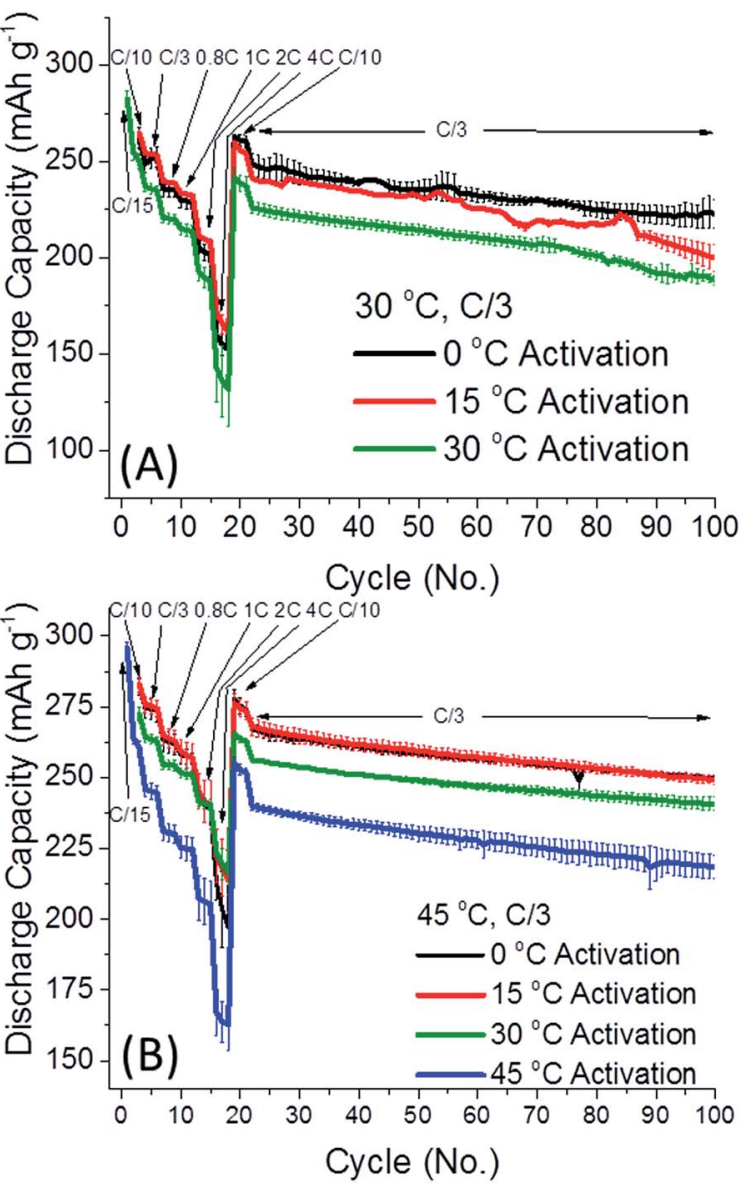

Fig. 1 The discharge capacity of $0.35 \mathrm{Li}_{2} \mathrm{MnO}_{3} \cdot 0.65 \mathrm{Li}\left[\mathrm{Mn}_{0.45} \mathrm{Ni}_{0.35^{-}}\right.$ $\mathrm{CO}_{0.20} \mathrm{JO}_{2}$ electrodes cycled at (A) $30^{\circ} \mathrm{C}$ and (B) $45^{\circ} \mathrm{C}$, after activation at either $0{ }^{\circ} \mathrm{C}$ (black), $15^{\circ} \mathrm{C}$, (red), $30^{\circ} \mathrm{C}$ (green), or $45^{\circ} \mathrm{C}$ (blue). For $1 \mathrm{C}$ rate the capacity of $250 \mathrm{~mA} \mathrm{~h} \mathrm{~g}^{-1}$, used for all cells. Error bars represent 1 std. deviation amongst $3-4$ cells.

this case as $\sim 108 \mathrm{~mA} \mathrm{~h} \mathrm{~g}^{-1}$ in comparison with $\sim 170 \mathrm{~mA} \mathrm{~h} \mathrm{~g}^{-1}$ for the other electrodes. $\mathrm{Li}_{2} \mathrm{MnO}_{3}$ may be represented in the form $\mathrm{Li}\left[\mathrm{Li}_{1 / 3} \mathrm{Mn}_{2 / 3}\right] \mathrm{O}_{2}$, with the $\mathrm{Li}^{+}$inside the brackets referring to the lithium in the TM layer. ${ }^{18}$ Prior to activation above $4.5 \mathrm{~V}$, $\mathrm{Li}^{+}$is only extracted from the Li-layer:

$$
\mathrm{Li}\left[\mathrm{Li}_{1 / 3} \mathrm{Mn}_{2 / 3}\right] \mathrm{O}_{2} \rightarrow \mathrm{Li}_{1 / 3} \mathrm{Mn}_{2 / 3} \mathrm{O}_{2}+\mathrm{Li}^{+}+\mathrm{e}^{-}
$$

The oxidation peak at $>4.5 \mathrm{~V}$ corresponds to the removal of $\mathrm{Li}^{+}$concomitant with $\mathrm{O}_{2}$ release in a complex activation process beyond the scope of this communication. ${ }^{7,19}$ After this activation process, $\mathrm{Li}^{+}$may be removed from the TM layer, and $\mathrm{Mn}^{3+/}$ ${ }^{4+}$ and $\mathrm{O}^{2-}$ /peroxo-dimer redox processes become active. ${ }^{\mathbf{1 1 , 1 2}}$

The activation process involving the extraction of $\mathrm{Li}^{+}$from the TM layer are reflected by 3 peaks in Fig. 3. All $\mathrm{d} Q / \mathrm{d} V$ and voltage profiles were taken from one representative cell since they cannot be reasonably averaged. First, the irreversible activation peak occurs, labelled 1 , shifting to higher potentials when $0.35 \mathrm{Li}_{2} \mathrm{MnO}_{3} \cdot 0.65 \mathrm{Li}\left[\mathrm{Mn}_{0.45} \mathrm{Ni}_{0.35} \mathrm{Co}_{0.20}\right] \mathrm{O}_{2}$ electrodes are activated at lower temperatures. Once the electrode is activated, reversible redox peaks at $c a$. $3.6 \mathrm{~V}$ (labelled 2 in Fig. 3C), believed to be related to $\mathrm{Li}^{+}$removal from the $\mathrm{TM}$ layer, is 

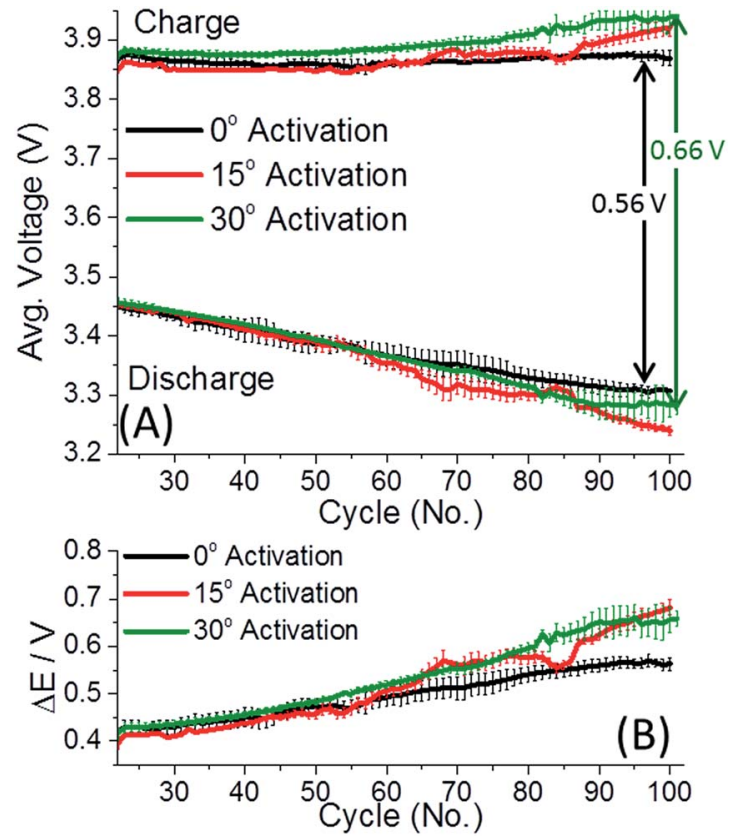

Fig. 2 (A) The average charge and discharge voltages of $0.35 \mathrm{Li}_{2}-$ $\mathrm{MnO}_{3} \cdot 0.65 \mathrm{Li}\left[\mathrm{Mn}_{0.45} \mathrm{Ni}_{0.35} \mathrm{Co}_{0.20}\right] \mathrm{O}_{2}$ electrodes activated at either $0{ }^{\circ} \mathrm{C}$ (black), $15^{\circ} \mathrm{C}$, (red), or $30^{\circ} \mathrm{C}$ (green) and cycled at $30^{\circ} \mathrm{C}$ at a $\mathrm{C} / 3$ rate. (B) The average charge-discharge voltage difference, $\Delta E$, of the cells presented in (A). Initial rate capability cycles are omitted for clarity since average voltage changes with rate. Error bars represent 1 std. deviation among 3-4 cells.

followed by a third peak, $3, \mathrm{Li}^{+}$removal from the Li-layer. ${ }^{19}$ The higher potential peaks can be attributed to redox activity of layered $\mathrm{Li}(\mathrm{TM}) \mathrm{O}_{2}$ component, so are omitted from discussion. ${ }^{7}$ Thus, we conclude that at $0{ }^{\circ} \mathrm{C}$ the only redox activity at the $2^{\text {nd }}$ cycle originates from the $\mathrm{Li}(\mathrm{TM}) \mathrm{O}_{2}$ domain. We also observe that peak 2 is much more pronounced for cells activated at $15{ }^{\circ} \mathrm{C}$, slightly lower for cells activated at $30^{\circ} \mathrm{C}$ and the lowest for $45{ }^{\circ} \mathrm{C}$. The trend is opposite for peak 3 . Therefore, we conclude that low- $T$ activation improves subsequent $\mathrm{Li}^{+}$extraction from TM layers. The effect of low- $T$ activation is further exhibited in Fig. 4 , related to the $3^{\text {rd }}$ and $4^{\text {th }}$ cycles of cells after activation, at $30{ }^{\circ} \mathrm{C}$. It is important to note that $0.35 \mathrm{Li}_{2} \mathrm{MnO}_{3} \cdot 0.65 \mathrm{Li}\left[\mathrm{Mn}_{0.45^{-}}\right.$ $\left.\mathrm{Ni}_{0.35} \mathrm{Co}_{0.20}\right] \mathrm{O}_{2}$ electrodes activated initially at $0{ }^{\circ} \mathrm{C}$ are activated further in third cycle (the oxidation peak 1, Fig. $4 \mathrm{~A}$ and $\mathrm{B}$ ). In contrast, for the samples activated at $15^{\circ} \mathrm{C}$, peak 1 is missing in Fig. 4, indicating that activation was completed during the first two cycles.

Here we should note that previous "window opening" experiments by other groups have shown that slow activation of the Li-rich electrodes through stepwise increasing anodic potential limits can also increase discharge capacity. ${ }^{\mathbf{8 , 9 2 0 - 2 2}}$ Hence it is suggested that the mechanism behind low- $T$ activation in our study involves a slower activation of the material conferred both by a step-wise increase of potential as in the "window opening" pre-treatments and diminished thermal agitation during electrodes' activation at low temperature. Cycling improvements conferred by low- $T$ activation may be due to a slower and partial structural reorganization of $\mathrm{Li}_{2} \mathrm{MnO}_{3}$ that
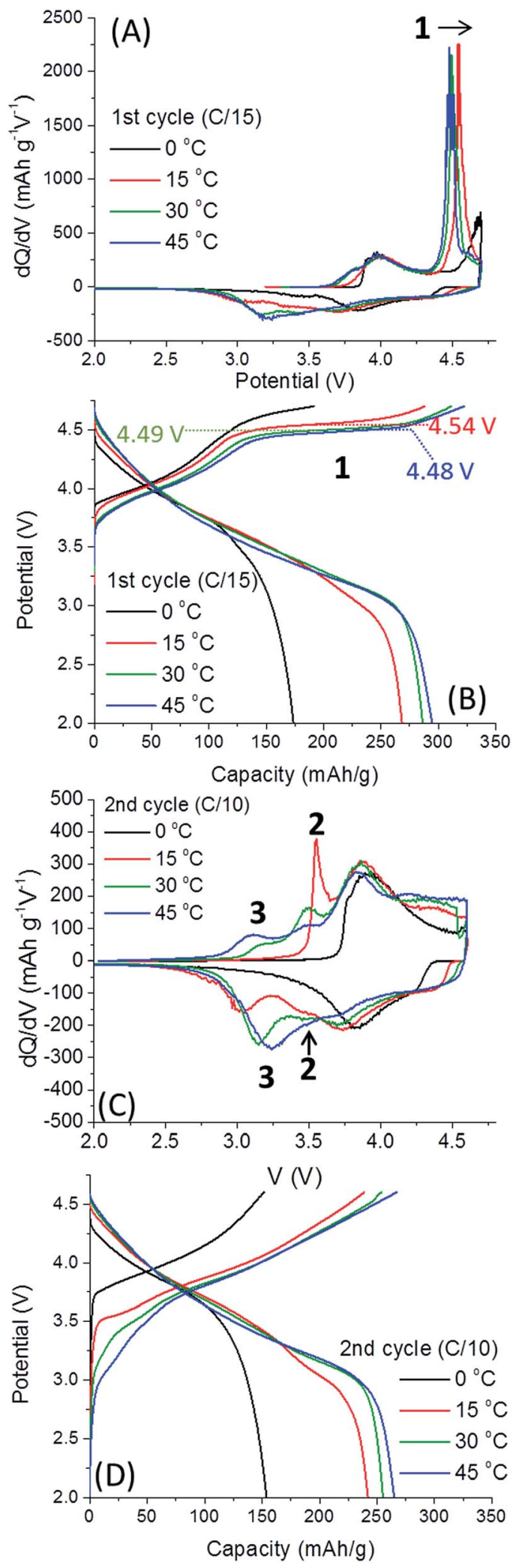

Fig. 3 Differential capacity $d Q / d V$ vs. voltage plots and charge/ discharge profiles for the activation step, including the $1^{\text {st }}$ cycle (A and $B$ ) at a $C / 15$ rate and the second cycle (C and D) at a C/10 rate of $0.35 \mathrm{Li}_{2} \mathrm{MnO}_{3} \cdot 0.65 \mathrm{Li}\left[\mathrm{Mn}_{0.45} \mathrm{Ni}_{0.35} \mathrm{CO}_{0.20}\right] \mathrm{O}_{2}$ electrodes, carried out at $0-45^{\circ} \mathrm{C}$. Redox peaks involving $\mathrm{Mn}$ are labeled $1-3$, which progress from 1 to 3 during cycling. 

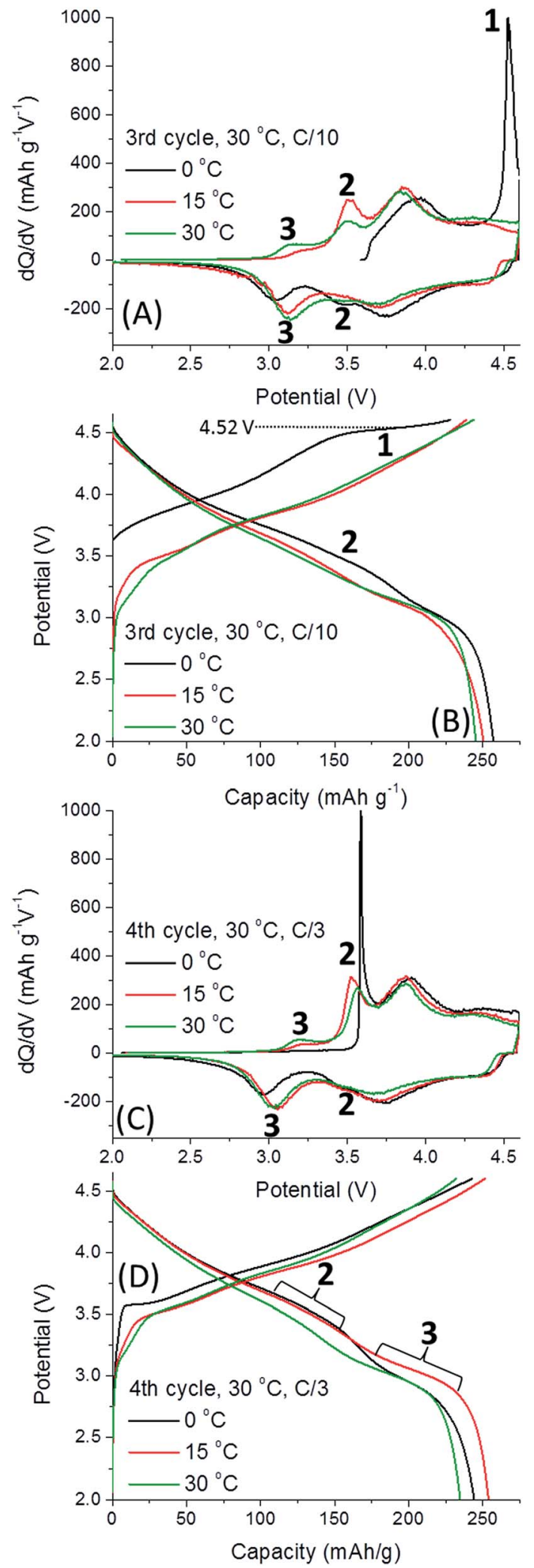

Fig. 4 Differential capacity, $d Q / d V$ vs. voltage plots and charge profiles for the $3^{\text {rd }}$ cycle $(A$ and $B)$ and $4^{\text {th }}$ cycle ( $C$ and $\left.D\right)$, at $30^{\circ} \mathrm{C}$, after the formation cycles of $0.35 \mathrm{Li}_{2} \mathrm{MnO}_{3} \cdot 0.65 \mathrm{Li}\left[\mathrm{Mn}_{0.45} \mathrm{Ni}_{0.35} \mathrm{CO}_{0.20}\right] \mathrm{O}_{2}$ electrodes. Redox peaks/voltage plateaus involving $\mathrm{Mn}$ are labeled 2 and 3 . permits greater $\mathrm{Li}^{+}$extraction from the TM-layer, and a smaller amount of the surface $\mathrm{O}_{2}$ released. In Fig. 4B the activation plateau is at $4.52 \mathrm{~V}$, similarly to the cell activated at $30{ }^{\circ} \mathrm{C}$ (Fig. 3B). For the cells activated at $0{ }^{\circ} \mathrm{C}$, upon the third cycle at $30{ }^{\circ} \mathrm{C}$, oxidation peak 1 is extremely intense, and reduction peaks 2 and 3 appear, indicating further activation occurs (Fig. 4A and B). We suggest that low- $T$ activation stimulates retaining the $\mathrm{Li}_{2} \mathrm{MnO}_{3}$ structure with redox activity involving the $\mathrm{Li}^{+}$ions re-insertion into the TM layer. This provides the highest discharge capacity, $\sim 260 \mathrm{~mA} \mathrm{~h} \mathrm{~g}{ }^{-1}$, by the $3^{\text {rd }}$ cycle (Fig. 4B). Fig. 4C illustrates that peak $2\left(\mathrm{Li}^{+}\right.$extraction from/ insertion to the TM layer) for the electrode activated at $0{ }^{\circ} \mathrm{C}$ is extremely sharp, well defined and is highest for this cell. The intensity of this peak decreases for the $15{ }^{\circ} \mathrm{C}$ cells, and it is the lowest for the $30{ }^{\circ} \mathrm{C}$ cells. The opposite evolution was established occurring for peak $3\left(\mathrm{Li}^{+}\right.$insertion into the Li-layer).

The mechanism behind low- $T$ activation at $0{ }^{\circ} \mathrm{C}$ resulting in several improvements, like capacity increase, decrease in average charge voltage, its stabilization, and diminished voltage hysteresis upon cycling of $0.35 \mathrm{Li}_{2} \mathrm{MnO}_{3} \cdot 0.65 \mathrm{Li}\left[\mathrm{Mn}_{0.45} \mathrm{Ni}_{0.35^{-}}\right.$ $\left.\mathrm{Co}_{0.20}\right] \mathrm{O}_{2}$, remains incompletely understood. Our hypothesized mechanism is that the slower and gradual activation of these electrodes at $0{ }^{\circ} \mathrm{C}$ permits slower structural activation/ reorganization of the $\mathrm{Li}_{2} \mathrm{MnO}_{3}$ component, resulting in a greater degree of the TM layer accessible for $\mathrm{Li}^{+}$re-insertion. Thermal activation also involves the slight shifting of the activation potential window, so this also likely plays a role in slowing the activation mechanism similar to potential "window opening". We suggest that the low- $T$ activation effect is in line with the observation reported recently by Thackeray et al. that lower charge-discharge voltage (hysteresis) in $x \mathrm{Li}_{2} \mathrm{MnO}_{3} \cdot(1-x)$ $\mathrm{Li}(\mathrm{TM}) \mathrm{O}_{2}$ electrodes results from the non-activated $\mathrm{Li}_{2} \mathrm{MnO}_{3}$ component. ${ }^{8}$ One of the questions that motivated our research was to evaluate whether the phenomenon of the lowtemperature electrode activation relates to a surface or bulk dominated processes. Aiming this, we explored these cathodes by impedance spectroscopy, which enable separation of the various time constants determining the electrode kinetics. The impedance spectra of $0.35 \mathrm{Li}_{2} \mathrm{MnO}_{3} \cdot 0.65 \mathrm{Li}\left[\mathrm{Mn}_{0.45} \mathrm{Ni}_{0.35} \mathrm{Co}_{0.20}\right]$ $\mathrm{O}_{2}$ electrodes are presented in Fig. 5. For these measurements, electrodes after activation at different temperatures underwent 2 cycles at $45{ }^{\circ} \mathrm{C}$ and were measured at this temperature, in order to compare the impedance of all the electrodes at the same temperature. They were then brought to the potentials of interest $(3.8,3.9$ and $4.0 \mathrm{~V})$, and held for $10 \mathrm{~h}$ potentiostatically to establish a constant potential. Impedance spectra were measured from $500 \mathrm{kHz}$ to $5 \mathrm{mHz}$, as described in ref. 3. Small increases in the surface film resistance of these electrodes (calculated from the diameter of the high-to-medium frequency semicircle) are observed as a function of temperature in the range $0-30 \quad{ }^{\circ} \mathrm{C}$. The high-medium frequency impedance becomes pronouncedly higher when the activation was carried out at $45{ }^{\circ} \mathrm{C}$. The impedance spectra are potential dependent. This is expected, since the spectral features presented reflect also time constants related to charge transfer processes. In general, once the electrodes become passivated, their surface film should not change dramatically upon cycling. ${ }^{23}$ The most 

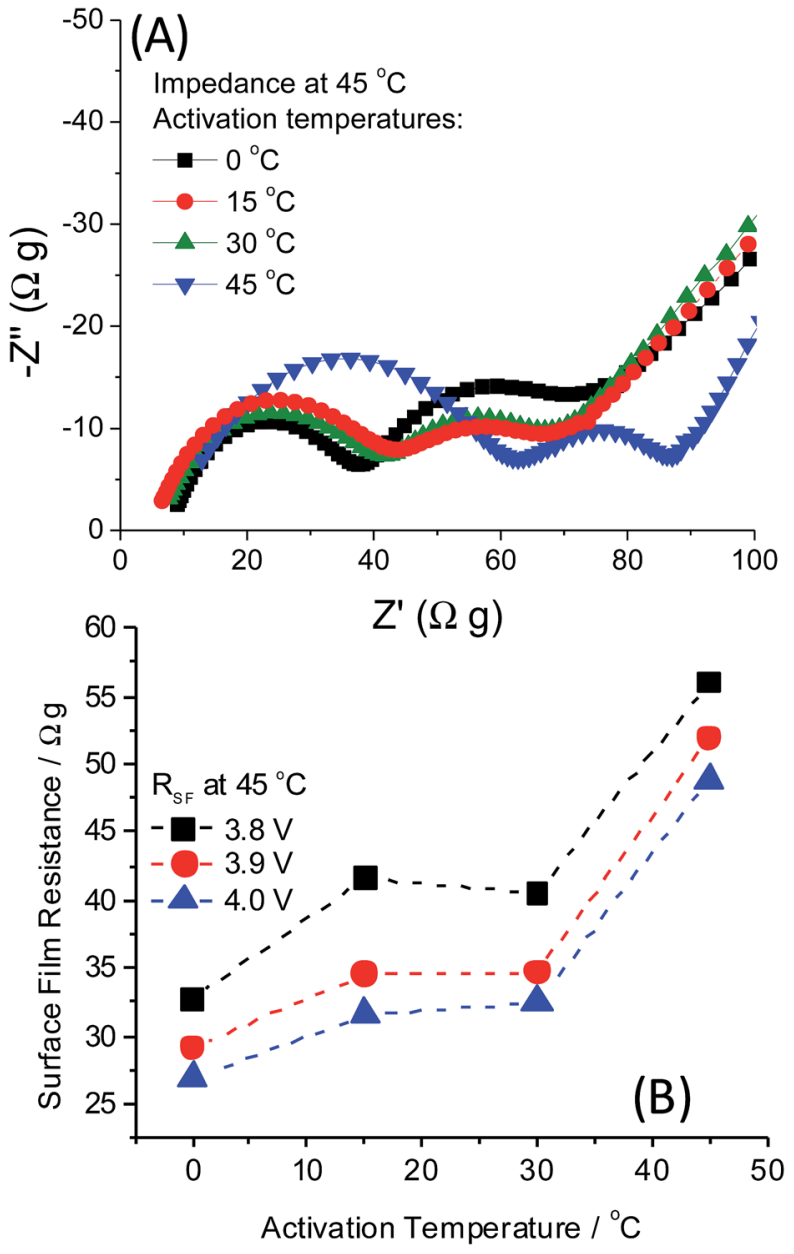

Fig. 5 (A) Representative impedance spectra at $4.0 \mathrm{~V}$ of $0.35 \mathrm{Li}_{2}$ $\mathrm{MnO}_{3} \cdot 0.65 \mathrm{Li}\left[\mathrm{Mn}_{0.45} \mathrm{Ni}_{0.35} \mathrm{Co}_{0.20}\right] \mathrm{O}_{2}$ electrodes activated at $0{ }^{\circ} \mathrm{C}$ (black), $15{ }^{\circ} \mathrm{C}$ (red), $30^{\circ} \mathrm{C}$ (green) and $45^{\circ} \mathrm{C}$ (blue) after the first two formation cycles, at $45^{\circ} \mathrm{C}$. (B) The surface film resistance, $R_{\mathrm{SF}}$, calculated from the first semi-circle of the Nyquist plots in (A), plotted as a function of the activation temperature.

important finding in Fig. 5 was that both the surface aspects represented by the high-medium frequency semicircles in the spectra (may reflect the nature of the surface films, formation of surface vacancies and defects) and bulk aspects (reflected by the low frequency impedance) are affected by the activation temperature (Fig. 5B). This makes the low temperature (e.g. $0{ }^{\circ} \mathrm{C}$ ) activation a complex phenomenon, in which both surface and bulk structural aspects are involved. These preliminary studies by EIS, prove further that the temperature dependent activation described herein requires more studies. Hence, in this paper we describe the basic phenomenon of the temperature-affected activation, with an emphasis on electrochemical studies only. Further work is focused on intensive structural analysis and search for peculiarities of Li-rich materials' activation at low temperatures and elucidation of its mechanism. On-going work includes also quantitative analysis of gas evolution by on-line (operando) mass spectrometry, which can monitor $\mathrm{O}_{2}$ and other gases evolved during activation at different temperatures. ${ }^{\mathbf{2 4}, 25}$ Additionally, the long-term cycle- ability of these cathode materials is of the highest importance for commercial applications and hence, their capacity and voltage stability in full cells should be demonstrated. Fig. S3 in the ESI $\dagger$ depicts the changes in the electrode $\mathrm{d} Q / \mathrm{d} V$ plots over 100 cycles, which show that low- $T$ activation does not eliminate the fading mechanisms associated with Li-rich electrodes, but yet may improve stability even during prolonged cycling. The present prompt report on the surprising low temperature activation effect stimulates further intensive mechanistic research.

\section{Notes and references}

1 F. Amalraj, M. Talianker, B. Markovsky, D. Sharon, L. Burlaka, G. Shafir, E. Zinigrad, O. Haik, D. Aurbach, J. Lampert, M. Schulz-Dobrick and A. Garsuch, J. Electrochem. Soc., 2012, 160, A324-A337.

2 F. Amalraj, D. Kovacheva, M. Talianker, L. Zeiri, J. Grinblat, N. Leifer, G. Goobes, B. Markovsky and D. Aurbach, J. Electrochem. Soc., 2010, 157, A1121.

3 F. Amalraj, M. Talianker, B. Markovsky, L. Burlaka, N. Leifer, G. Goobes, E. M. Erickson, O. Haik, J. Grinblat, E. Zinigrad, D. Aurbach, J. K. Lampert, J.-Y. Shin, M. Schulz-Dobrick and A. Garsuch, J. Electrochem. Soc., 2013, 160, A2220-A2233.

4 R. Shunmugasundaram, R. S. Arumugam and J. R. Dahn, J. Electrochem. Soc., 2016, 163, A1394-A1400.

5 C. Genevois, H. Koga, L. Croguennec, M. Menetrier, C. Delmas and F. Weill, J. Phys. Chem. C, 2015, 119, 75-83.

6 A. K. Shukla, Q. M. Ramasse, C. Ophus, H. Duncan, F. Hage and G. Chen, Nat. Commun., 2015, 6, 8711.

7 J. R. Croy, D. Kim, M. Balasubramanian, K. Gallagher, S.-H. Kang and M. M. Thackeray, J. Electrochem. Soc., 2012, 159, A781-A790.

8 J. R. Croy, K. G. Gallagher, M. Balasubramanian, Z. Chen, Y. Ren, D. Kim, S.-H. Kang, D. W. Dees and M. M. Thackeray, J. Phys. Chem. C, 2013, 117, 6525-6536.

9 J. R. Croy, K. G. Gallagher, M. Balasubramanian, B. R. Long and M. M. Thackeray, J. Electrochem. Soc., 2014, 161, A318A325.

10 E. M. Erickson, C. Ghanty and D. Aurbach, J. Phys. Chem. Lett., 2014, 5, 3313-3324.

11 E. McCalla, A. M. Abakumov, M. Saubanere, D. Foix, E. J. Berg, G. Rousse, M.-L. Doublet, D. Gonbeau, P. Novak, G. Van Tendeloo, R. Dominko and J.-M. Tarascon, Science, 2015, 350, 1516-1521.

12 E. McCalla, M. T. Sougrati, G. Rousse, E. J. Berg, A. Abakumov, N. Recham, K. Ramesha, M. Sathiya, R. Dominko, G. Van Tendeloo, P. Novak and J.-M. Tarascon, J. Am. Chem. Soc., 2015, 137, 4804-4814.

13 E. McCalla, A. S. Prakash, E. Berg, M. Saubanere, A. M. Abakumov, D. Foix, B. Klobes, M.-T. Sougrati, G. Rousse, F. Lepoivre, S. Mariyappan, M.-L. Doublet, D. Gonbeau, P. Novak, G. Van Tendeloo, R. P. Hermann and J.-M. Tarascon, J. Electrochem. Soc., 2015, 162, A1341A1351.

14 Y.-S. Hong, Y. J. Park, K. S. Ryu, S. H. Chang and M. G. Kim, J. Mater. Chem., 2004, 14, 1424-1429. 
15 N. Yabuuchi, M. Takeuchi, M. Nakayama, H. Shiiba, M. Ogawa, K. Nakayama, T. Ohta, D. Endo, T. Ozaki, T. Inamasu, K. Sato and S. Komaba, Proc. Natl. Acad. Sci. U. S. A., 2015, 112, 7650-7655.

16 M. Sathiya, A. M. Abakumov, D. Foix, G. Rousse, K. Ramesha, M. Saubanere, M. L. Doublet, H. Vezin, C. P. Laisa, A. S. Prakash, D. Gonbeau, G. VanTendeloo and J. M. Tarascon, Nat. Mater., 2015, 14, 230-238.

17 B. Qiu, J. Wang, Y. G. Xia, Z. Wei, S. J. Han and Z. P. Liu, J. Power Sources, 2014, 268, 517-521.

18 K. A. Jarvis, Z. Deng, L. F. Allard, A. Manthiram and P. J. Ferreira, Chem. Mater., 2011, 23, 3614-3621.

19 D. Mohanty, S. Kalnaus, R. A. Meisner, K. J. Rhodes, J. Li, E. A. Payzant, D. L. Wood Iii and C. Daniel, J. Power Sources, 2013, 229, 239-248.
20 T. Ohzuku, M. Nagayama, K. Tsuji and K. Ariyoshi, J. Mater. Chem., 2011, 21, 10179-10188.

21 A. Watanabe, F. Matsumoto, M. Fukunishi, G. Kobayashi, A. Ito, M. Hatano, Y. Ohsawa and Y. Sato, Electrochemistry, 2012, 80, 561-565.

22 A. Ito, D. Li, Y. Ohsawa and Y. Sato, J. Power Sources, 2008, 183, 344-346.

23 E. M. Erickson, H. Bouzaglo, H. Sclar, K.-J. Park, B.-B. Lim, F. Schipper, C. Ghanty, J. Grinblat, B. Markovsky, Y.-K. Sun and D. Aurbach, J. Electrochem. Soc., 2016, 163, A1348A1358.

24 A. Guéguen, D. Streich, M. He, M. Mendez, F. F. Chesneau, P. Novák and E. J. Berg, J. Electrochem. Soc., 2016, 163, A1095-A1100.

25 R. Bernhard, M. Metzger and H. A. Gasteiger, J. Electrochem. Soc., 2015, 162, A1984-A1989. 